Cici Karaboğa, E. N. ve Bilginer Özsaatcı, F. G. (2021). "The Impact of Crisis Perception on Consumer Purchasing Behaviors During the COVID-19 (Coronavirus) Period: A Research on Consumers in Turkey", Eskişehir Osmangazi Üniversitesi iiBF Dergisi, 16(3), 727 - 754.

Doi: 10.17153/oguiibf.923025

Başvuru: 03.05.2021 Kabul: 14.08.2021

Araştırma Makalesi/Research Article

\title{
The Impact of Crisis Perception on Consumer Purchasing Behaviors During the COVID-19 (Coronavirus) Period: A Research on Consumers in Turkey
}

\begin{tabular}{|c|c|}
\hline $\begin{array}{l}\text { COVID-19 (Koronavirüs) Sürecindeki Kriz Algısının } \\
\text { Tüketicilerin Satın Alma Davranışlarına Etkisi: } \\
\text { Türkiye'deki Tüketiciler Üzerine Bir Araştırma }\end{array}$ & $\begin{array}{l}\text { The Impact of Crisis Perception on Consumer } \\
\text { Purchasing Behaviors During the COVID-19 } \\
\text { (Coronavirus) Period: A Research on Consumers in } \\
\text { Turkey }\end{array}$ \\
\hline $\begin{array}{l}\text { Öz } \\
\text { Bu çalışma, Covid-19 döneminde kriz algısının tüketici } \\
\text { satın alma davranışlarına etkisini belirlemeyi } \\
\text { amaçlamaktadır. Bu amaçla, Türkiye'de karantinada olan } \\
\text { ve satın alma sürecinde karar verici pozisyonundaki } \\
\text { bireylere anket uygulanmıştır. Çalışmanın hipotezleri } \\
\text { korelasyon ve çoklu regresyon ile test edilmiştir. } \\
\text { Analizler sonucunda Covid-19 sürecinde tüketicilerdeki } \\
\text { kriz algısının satın alma davranışı düzeyinde ve kriz algısı } \\
\text { alt boyutlarından tutumluluk ve ihtiyatlılığın da satın } \\
\text { alma davranışı düzeyinde pozitif yönlü anlamlı etkiye } \\
\text { sahip olduğu, ancak gelecek kaygısı alt boyutunun ise } \\
\text { satın alma davranışı düzeyinde pozitif yönlü anlamlı } \\
\text { etkiye sahip olmadığı tespit edilmiştir. Fark testleri } \\
\text { sonucunda yalnızca maaş kısıtlamasına maruz kalmanın } \\
\text { kriz algısı üzerinde anlamlı bir farklılığa neden olduğu } \\
\text { belirlenmiştir. }\end{array}$ & $\begin{array}{l}\text { Abstract } \\
\text { This study aims to determine the impact of crisis } \\
\text { perception on consumer purchasing behaviors during } \\
\text { the Covid-19 period. To this end, a survey has been } \\
\text { conducted with citizens who are in quarantine and hold } \\
\text { a decision-making position in making purchases. The } \\
\text { study's hypotheses were tested with correlation and } \\
\text { multiple regression. These analyzes pointed out that } \\
\text { crisis perception among consumers during the Covid-19 } \\
\text { and sparingness and cautiousness, which are the sub- } \\
\text { dimensions of crisis perception had positive and } \\
\text { significant effect on purchasing behavior; however, the } \\
\text { study determined that concern for the future sub- } \\
\text { dimension did not have positive and significant effect on } \\
\text { purchasing behavior. The results of the difference tests } \\
\text { revealed that only wage restrictions caused a significant } \\
\text { difference in crisis perception. }\end{array}$ \\
\hline $\begin{array}{l}\text { Anahtar Kelimeler: Covid-19, Tüketici Satın Alma } \\
\text { Davranışı, Kriz Algısı, Pandemi Dönemi }\end{array}$ & $\begin{array}{l}\text { Keywords: Covid-19, Consumer Purchasing Behavior, } \\
\text { Crisis Perception, Pandemic Period }\end{array}$ \\
\hline JEL Kodları: M31 & JEL Codes: M31 \\
\hline $\begin{array}{l}\text { Bu çalışma 06.06.2020 tarih ve 804.01-E.20060 } \\
\text { Alt Çalışma Grubu tarafından verilen Etik Kurul } \\
\text { olarak hazırlanmıştır. }\end{array}$ & $\begin{array}{l}06 \text { sayılı Hasan Kalyoncu Üniversitesi Ölçme Değerlendirme Etik } \\
\text { nay Belgesi ile bilimsel araştırma ve yayın etiği kurallarına uygun }\end{array}$ \\
\hline Yazar 1'in makaleye katkısı \%50, Yazar 2'nin ma & aleye katkısı \%50'dir. \\
\hline rlar açısından ya da üçüncü taraflar açısınd & çalışmadan kaynaklı çıkar çatışması bulunmamaktadır. \\
\hline
\end{tabular}

1 Dr. Öğr. Üyesi, Necmettin Erbakan Üniversitesi, Uygulamalı Bilimler Fakültesi, Yönetim Bilişim Sistemleri, enihancici@erbakan.edu.tr

2 Dr. Öğr. Üyesi, Hasan Kalyoncu Üniversitesi, İktisadi İdari ve Sosyal Bilimler Fakültesi, İşletme, fatmagul.bilginer@hku.edu.tr 


\section{Introduction}

During the COVID-19 pandemic, the changes that occurred in the economy and business world have also affected social life. In this period, the social life and consumption habits of consumers who have moved away from their workplaces to stay at home have changed.

This crisis, which affects the social life as well as the business world and economy in a short span of time, has changed individuals' social lives and standards of living from an economic point of view. This change has impacted both consumers' social habits and purchasing decisions. Consumers are one of the cornerstones that determine the sustainability of businesses and the survival of national economies. In this context, it is important to examine this crisis experienced by consumers, to perceive this process from consumers' point of view and to determine the change in their purchasing behaviors.

Considering the significance of psychological and behavioral factors of individuals during the pandemic, it is of utmost importance to evaluate their psychological and behavioral responses to the changes resulting from the pandemic, and to determine the association between crisis perception and consumer purchasing behavior.

The perception of economic crisis causes a change in purchasing behaviors by affecting consumers' psychology and purchasing power that is one of the factors that guide consumer purchasing behaviors.

The pandemic has forced consumers to change their attitudes and purchasing habits. Consumers stated that they were more concerned with the economic effects of Covid-19 than their health (Wright and Blackburn, 2020).

Consumers are reconsidering their purchasing decisions due to health and economic problems, scarcity of resources and panic purchasing (Prentice et al., 2021), more common concerns for security or protection, and contactless payment (Mehrolia et al., 2020). The pandemic may cause some people to become vulnerable and/or resistant and may bring about a negative environment that affects their purchasing decisions (Kursan Milaković, 2021).

While many studies examine consumer behavior with regards to the effects of COVID-19 (Ali, 2020; Arora et al., 2020; Bakkar, 2020; Chauhan \& Shah, 2020; Grashuis, et al., 2020; Pathak \& Warpade, 2020; Laato et al., 2020; Patil \& Patil, 2020; Sheth, 2020; Stanclu, et al.,2020; Zwanka \& Buff, C, 2020; Wang et al. 2020; Chenarides et al.,2021; Ellison et al., 2021; Peng \& Chen, 2021; Sayyida et al., 2021; Yadav \& Kumar, 2021; Zwanka \& Buff, 2021), the studies on consumer purchasing behavior are limited and they are mostly focused on panic purchasing.

The impact of the COVID-19 pandemic on the perception of economic crisis and consumer behavior is a critical issue not only in the short-term plans of businesses worldwide but also in the medium- and long-term revision of their strategies. In this context, determining the impact of the pandemic on consumer purchasing behavior is also of utmost importance.

The present study aims to determine the effect of economic crisis perception caused by the COVID-19 pandemic period on consumer purchasing behaviors. Therefore, the conceptual framework was included in the first part of the study while the COVID-19 pandemic, economic crisis perception, and consumer purchasing behavior were examined to reveal the correlation between them. The second part of the study included the methodology of the research, and 
the analysis of the data and the research findings were included in the third part. Lastly, we proposed some suggestions by evaluating the general results of the study.

\section{Conceptual Model and Hypothesis Development}

\subsection{COVID-19 Pandemic Period}

Coronavirus, which has firstly been diagnosed in China in December 2019, is affecting 215 countries around the world according to the report released by the World Health Organization (WHO) in June 2020. Coronavirus disease (COVID-19) is an infectious disease caused by the novel Coronavirus (WHO 2020; worldofmeters 2020).

The effects of the epidemic have been manifested differently across various countries depending on the general health of the population, development of disease cases, economic welfare, the level of development and modernization of the national medical system, and the scope of measures taken by decision-makers (Krishnamurthy \& Gopinath, 2020). The measures taken to prevent the spread of the pandemic have a considerable impact on industries such as tourism, retail, transportation, and agriculture (Stephany et al., 2020).

From this point of view, while the pandemic has become a major health crisis in the global sense, it has also led to a major crisis in economic and social terms.

\subsection{Crisis Perception}

The economic crisis, which is defined as the events that occur suddenly in different forms in the economy and cause decreases in a temporary period with devastating effects, accompanied by inflationary and deflationary trends in product and service prices, monetary policy, interest rates, revaluation or devaluation of the national currency relative to other currencies and tax policies situations arise (Huthincs, 2008; Erol, 2010). For this reason, it has a great impact on consumers, especially on the country's economy.

Crises that cause negative perceptions among individuals adversely affect their mental state and feelings and thoughts about the future. In particular, high crisis perception may lead to anxiety, pessimism, panic, and depression in the long term (Jasiulewicz, 2012:87). These perceptions that emerged due to a crisis affect consumers' purchasing behaviors as well as their values and opinions on different issues (Lee et al., 2003:488). Some studies revealed that the consumers have developed different behaviors against the negative effects of a crisis as a result of the differentiation of consumers' perceptions of a challenging process such as crises (Amalia and Lonut, 2009).

Consumers develop two types of responses against a crisis: reactive and proactive responses. Reactive response occurs when the consumer adapts to the current situation, changes their priorities by reassessing the needs and postpones or eliminates unnecessary costs, and prioritizes purchasing basic needs. In proactive response, assets are monetized to obtain cash and other types of responses such as saving, different types of loans or applying for a second job and taking part in illegal activities occur (Zurawicki and Braidot, 2005:1101). These approaches used by consumers faced with a crisis also affect consumer purchasing behavior.

\subsection{Consumer Purchasing Behavior}

Factors affecting consumer purchasing behavior are generally classified as sociological, socio-cultural, demographic, and situational. Situational effects refer to the changes in the environment where the purchasing decision is taken and include the physical environment, 
social environment, time, reason for purchasing, emotional and financial status (Odabaşı and Barış, 2013). In this context, the perception of crisis affecting individuals and society in terms of their perception and finances will also have an impact on purchasing behavior as a situational effect.

There are many factors that affect individuals' purchasing behaviors. These may be listed as follows (Pride and Ferrell, 2000; Odabaşı and Barış, 2006; Hobbs, 2020; as cited in Temizkan, Güven, Yılmazer and Andsoy, 2021):

- Marketing factors (product design, price, incentive, packaging, positioning, and distribution)

- Consumer characteristics (age, gender, income level, educational background, location)

- Psychological factors (purchase motive, product perception, and attitude towards a product)

- Situational factors (physical conditions at the time of making a purchase, social environment, timing)

- Social factors (social status, reference groups)

- Cultural factors (religion, social class, local preferences)

- Crisis periods, pandemics, and economic factors.

The crises caused by pandemics may have a great impact on the purchasing behavior of consumers. People can quickly make adjustments in their behavior in order to feel safe and secure. (Kayabaşı, 2020).

\subsection{Relationship Between Economic Crisis Perception and Consumer Purchasing Behavior}

Although there is a high number of studies in the literature on consumer purchasing behavior, studies on crisis perception and consumer purchasing behavior are quite limited.

Psychological factors, in particular, have a strong effect on consumer behavior. The restrictive measures adopted during the pandemic and Covid-19 negatively impacted people's mental state. While consumers could take more feasible decisions before Covid-19, panic, fear and uncertainty about the future, starting with the onset of the Covid-19 pandemic and seeming to continue for a long time, usually affect people with regards to their psychology (Kayabaşı, 2020).

Some radical changes also took place in the lives of consumers because of crises. One of the areas where these changes are effective is the consumption habits of individuals. Due to the changes in the attitudes and behaviors of consumers after a crisis, studies in the literature explaining the consumer behaviors as they were before the crisis are insufficient. In addition, even if the crisis ends, consumers cannot fully return to the attitudes and behaviors they had in the pre-crisis period due to the trauma they experience during the crisis.

COVID-19 brought about some changes in consumer behavior patterns around the world. (Fernandes, 2020). In addition to causing changes in consumer behavior, the pandemic also had several long-term effects (Yendamuri et al., 2020). A survey conducted by Global Web Index in the USA and UK found that 8 out of 10 consumers have changed their behavior due to the coronavirus. Changes in people's lifestyles, purchasing behavior and the supply chain of businesses led to new phenomena. For example, as retailers closed their stores, consumers began to examine products and brands from a new perspective (Mander, 2020). Considering a 
number of changes that have taken place, especially with regards to social distancing in the new normal after the pandemic, consumer habits and purchasing behaviors are adjusted to the new environment and conditions (Tam, 2020).

Chen et al. (2020; as cited in Ahorsu et al., 2020) argue that the huge uncertainty directly diminishes consumers' willingness to consume when they feel unsafe and anxious even though there is no imminent threat to their economic security.

Consumer purchasing behavior is considered to be the sum of decision-making processes determined by some internal and external factors. The most influential external factor is economic instability. The depressing effects of economic crises have adversely affected both planned and unplanned purchasing behavior of all consumers (Sharma and Sonwalkar, 2013: 45)

Besides, some radical changes occur in the lives of consumers during times of crisis. One of the areas where these changes are effective is the consumption habits of individuals. Due to the changes in the attitudes and behaviors of consumers brought about by the crisis, the literature explaining the consumer behaviors as they were before the crisis is insufficient. In addition, even if the crisis ends, consumers cannot fully return to their pre-crisis attitudes and behaviors due to the trauma experienced in the crisis period.

Major changes in consumer behavior in the event of an economic crisis are related to the following aspects (Nie et al., 2010):

1. With the decrease in consumer confidence due to economic uncertainty, expenditure budgets are significantly reduced as well. Consumers regulate their future consumption by shopping less and reducing their purchasing frequency (Shao Changbin, 2009).

2. Consumers tend to be more rational and more sensitive to the prices of products or services. Consumers change their current purchasing habits and they worry about price and quality as they buy more goods.

3. Consumers show an interest in various changes in promotional tools. They assume a more logical and calm approach during economic crises and care about product prices and costs.

4. In financial crises, consumers change their shopping channels. They prefer online shopping as it enables them to compare prices in addition to being practical, fast, convenient, and more affordable.

As mentioned previously, individuals tend to change their social and economic lives by perceiving the pandemic as a crisis. One of the most common points where the effect of this change is seen is the consumption habits and the resulting purchasing behaviors.

The effects of the crisis, which has various effects on consumers, are divided into two categories: internal and external factors. Internal factors are related to personality and psychology while external factors refer to environmental factors independent of consumers (Perriman et al., 2010, 8).

As consumers have different structures, their perception of the crisis differentiates accordingly. This is an internal aspect and the factors contributing to that are risk attitude and risk perception. These two factors are influential in the emergence of different consumer 
groups by determining the attitudes and behaviors of consumers towards the crisis (Amalia and Lonut, 2009: 779-782).

The fear and anxiety created by the current economic and social crisis prominently affect both social behavior in general and purchasing behavior in particular (Oana, 2020).

Ang (2001) conducted a comparative study on Asian, American and Eastern-European consumers and businesses to determine the role of the nature of the crisis, socio-economic characteristics, trading dependencies, market complexity on consumer culture and business behavior.

Every aspect of the socio-economic situation has changed not only the way the consumer makes a purchase but especially the items they buy and the reason behind their purchase. Consumers in developed countries are more financially-conscious, responsible, and demanding compared to traditional consumers. Currently, consumers are becoming increasingly aware of all aspects of product purchasing from its design, safety, and origin to social and economic impact. Thus, consumers are more careful and aware of their ability to influence the world with their choices (Salzman and O'Reilly, 2010).

Kaytaz and Gül (2014) discussed the response of consumers to the economic crisis and the marketing insight gained from this experience. Thanks to the demographic characteristics of consumers, the solid structure of the financial sector, and government policies, the crisis was quickly overcome with an increase in consumption expenditures. During the initial shock, consumers preferred cheaper goods and total consumption expenditures decreased, however, the government's policies and support during the process were effective in increasing consumption.

The perceived risk due to the crisis may apparently affect individuals' behavior during a pandemic (Wise et al., 2020).

Another consequence of the rapid change in consumer behavior in crisis situations is that consumers develop a behavior of stockpiling, especially for food and basic consumption products. This has been observed in all consumers in different countries, especially in China (Wang, et al., 2020).

Baker et al. (2020) examined the household spending habits of consumers in the US during the first weeks of the epidemic. The study revealed that the COVID-19 period radically changed the expenditures of consumers in a wide variety of categories.

Based on all these studies, the main hypothesis of the research is as follows.

$\mathrm{H} 1$ = Crisis perception of consumers during the COVID-19 pandemic process has a positive significant effect on the purchasing behavior.

Consumers' purchasing behaviors tend to change in difficult and stressful times such as an economic crisis (Nistorescu and Puiu, 2009). Consumers who have been purchasing products that they do not actually need before the crisis are changing their decisions and attitudes about purchasing due to the effect of the economic recession caused by the crisis (Flatters and Willmott, 2009; Zhigalova, 2012). In particular, the formation of a crisis perception in economic terms causes consumers to reduce their expenditures and maintain this change (Leinwand et al., 2008:1).

The study conducted by Murrugarra and Signoret (2002) revealed that mostly urban and relatively advantaged classes in Moldova were affected by the crisis in Russia and that 
people's expenditures on health and education were reduced. They stated that this unexpected result was caused by the nature of the relevant crisis.

There are various country-specific studies based on household survey data. For example, McKenzie and Schargrodsky $(2005,2011)$ revealed that during the Argentine crisis in 2002, consumers' total consumption expenditures actually decreased, but they spent more time shopping. The reason for this is that consumers spend more time searching for lower-priced products and finding substitutes.

Kang and Sawada (2008) found out that Korean consumers tried to maintain their spending on food, education and health during the Asian crisis while reducing luxury consumption.

As a result of his study on the change in consumer purchasing behaviors during the economic crisis period, Berber (2009) found that consumers were more sparing in the crisis period, made purchases based on their needs, were financially concerned, tended to suppress their needs more frequently compared to the pre-crisis period, felt the pressure of the product/service pricing more intensely, made more comparisons between products, and were affected by their immediate circles in these periods.

Booz \& Company's study, which was carried out in 2009 with a total of 2,000 consumers in the United States, highlighted a "new type of sparing" that appeared at the beginning of the recession and noted the decline in per capita consumption in the first two years, stressing that this was experienced in an intense manner among the consumers in the US. New consumption patterns are expected to continue even if the economy improves. This new type of sparing is characterized by a strong awareness of the value that determines negotiations in terms of price, brand, and comfort. This sparing type also becomes the widespread mindset among the consumers in the US.. The new type of sparing and awareness of value are now driving consumer behaviors. Consumers continue to buy products at different prices, so they need more reasons to justify buying them independently of the price segment of the product. They clearly refuse to make a purchase at a higher price unless they perceive an advantage with regards to quality. If there are some brands they are loyal to, they prefer to wait for price reductions, promotions or discount coupons. They have strengthened the behavioral differences in the nature of this new attitude with demographic data such as gender, ethnicity, age as well as income. For instance, certain segments of the population (such as women, individuals with a low level of income, and middle-aged people) try to save money by buying products at discounted prices although consumers usually buy products from different price categories.

As consumers become more knowledgeable about the effects of the crisis and as the media focuses on these issues, an adverse psychological effect occurs on consumers, especially during times of crisis (Amalia and lonut, 2009).

The external factor that is felt more intensely during times of crisis is the uncertainty of the future. In such a period characterized by economic stagnation and numerous changes, consumers feel insecure. In this environment, consumers' inability to predict the future in economic terms leads to a tendency to make purchases more carefully in the future (Pop and Rosca, 2009).

Consumers who develop different perceptions and attitudes with regards to risk attitude and risk perception respond differently to a crisis. These responses of consumers affect their 
purchasing behaviors, habits, and attitudes towards brands. As a result, consumers make changes in their spending habits in periods of crisis, act more consciously concerning the prices, prefer to make more purchases during promotional periods, and change their points of purchase when necessary (Nie et al., 2010: 488).

Consumer purchasing behavior is considered to be the sum of decision-making processes determined by some internal and external factors. The most influential external factor is economic instability. The depressing effects of economic crises have adversely affected both planned and unplanned purchasing behavior of all consumers (Sharma and Sonwalkar, 2013: 45).

While internal and external factors affect the consumer's decision to purchase a product in normal situations (Asioli et al., 2017, Richardson et al., 1994), in cases of crisis perception such as the COVID-19 pandemic, consumers focus on the benefit of the product, make more purchases in the food industry, and pay less attention to the luxury goods and services (OECD, 2020).

All these studies have found that consumers are more sparing during periods of crisis and act cautiously while making purchasing decisions. In this context, the following hypotheses have been put forward to examine this phenomenon within the framework of the crisis that occurred during the COVID-19 pandemic.

H1a: The sparingness that consumers gain during the COVID-19 pandemic has a positive and statistically significant effect on the purchasing behavior.

H1b: The cautiousness that consumers gain during the COVID-19 pandemic has a positive and statistically significant effect on the purchasing behavior.

Askeona (1974) proposed that many people would have to make more purchases based on their needs if they believed that prices would increase more within a few months, and thus, they would use the smaller resources they have to buy the desired goods and services that are not mandatory. Therefore, inflation leads to the postponement of discretionary expenditures. People are motivated to make savings during periods of recession due to threats posed to their work or income. As economic conditions improve, the rates of making savings decrease.

In his study examining the adjustment mechanisms used by Mexican households during the Mexican peso crisis, McKenzie (2003) found that households resort to reducing fertility, increasing household labor supply when possible, increasing home education for children, and interhousehold transfers if it is not possible to increase the labor supply during the crisis. It has been revealed that there is a drastic decrease in consumption composition during the crisis period with some differences between the groups.

There have been major changes with market shrinkage due to the crisis. Consumers have changed their purchasing behavior. They began to worry about their jobs and no longer enjoyed spending their money. They postponed or reduced large amounts of purchases to be made for leisure and entertainment purposes. People started buying in lesser amounts or preferred larger sized products to avoid making re-purchases. They also began to change their preferred brands, focused on price rather than quality, and began to intensify their research on the web to compare prices (Perner, 2008; Drakopoulos, 2008). 
Considering all these studies, the H1c hypothesis is formulated as follows to examine the concern for the future affected by the COVID-19 pandemic.

H1c: The concern for the future that consumers have during the COVID-19 pandemic has a positive and statistically significant effect on the purchasing behavior.

The restrictive measures taken by countries during the covid-19 process have led to the emergence of a number of new economic practices. For example, Wage restrictions and the rotating working system. These measures brought about the economic crisis. This situation also had an impact on consumers' perception of crisis.

There are several country-specific studies using household interview survey data. For example, McKenzie and Schargrodsky $(2005,2011)$ found that during the time of the 2002 Argentine crisis, consumers' total consumption expenditures decreased in real terms, but they spent more time on shopping. They stated that the reason for this was that consumers spent time searching for products with lower prices and finding substitutes. Kang and Sawada (2008) found that Korean consumers tried to protect their spending on food, education and health and reduced their luxury consumption during the Asian crisis. When these studies were evaluated, the $\mathrm{H} 2$ hypothesis of the research was developed as follows:

H2: Wage restrictions for consumer salaries causes a significant difference in the perception of crisis.

Urbonavicius and Pikturniene (2010) conducted a study on the behaviors of two different generations of Lithuanian consumers in order to analyze the emotional responses of consumers based on the economic crisis. The results of the study revealed that the young generation tries to maintain their consumption levels while some members of the older generation reduce their consumption expenditures. Based on this study, the $\mathrm{H} 3$ hypothesis was developed in the study:

H3: There is a significant difference in purchasing behavior across generations.

When we review the literature, consumers are significantly affected by the crisis, however, they develop different responses when faced with a crisis. The present study investigated the effect of cautiousness, sparingness, and concern for the future developed by consumers when faced with the crisis on purchasing behavior and whether the concept of wage constraint that consumers are exposed to shows a significant difference across various generations.

\section{Research Methodology}

\subsection{Questionnaire Design, Data Collection, and Sampling}

In the present study, the questions of changing purchasing behavior of consumers with regards to the perception of economic crisis that Berber (2009) tried to measure were adapted to the crisis perception of the consumers during the COVID-19 pandemic period. There are three dimensions in the scale used to measure the crisis perception of consumers. Accordingly, when individuals perceive their situation as a crisis, they develop three different attitudes. These are sparingness, cautiousness, and concern for the future. Thus, the effect of these emerging attitudes on the purchasing behavior of individuals will be measured. The data of the research were collected with the online survey method. This survey, which is designed to determine the impact of crisis perception on consumer purchasing behaviors during the COVID-19 (Coronavirus) period, consists of four main dimensions. The first section 
contains multiple-choice questions about demographic variables. The second section is comprised of multiple-choice questions about the COVID-19 pandemic period. The third section includes the questions regarding "crisis perception" main dimension, consisting of 17 Likert-scale items (1: Completely Disagree, 5: Completely Agree) and 3 dimensions. The fourth section includes 19 Likert-scale (1: Completely Disagree, 5: Completely Agree) items and onedimensional "purchasing behavior" main dimension questions.

The study aimed to measure the changing purchasing behavior of citizens who are first quarantined in March 2020 with the spread of Coronavirus (2019-nCoV) that appeared in China in December 2019 into Turkey through an online survey.

In order to ensure the internal validity of the survey, we consulted experts in the relevant field. After their opinions were received, two questions that were difficult to understand were modified in linguistic aspects. With this newly organized survey, the pilot study was carried out with 30 people. As a result of the data obtained from this study, questions that were presumed to be misunderstood were identified. For all these reasons, the entire survey was presented to a linguist to be examined. The survey, which gained its last form after all these modifications, was delivered to consumers through social media accounts created during the quarantine.

The relevant online survey was published between 01.05.2020 and 20.05.2020 and the data was collected.

The research included citizens who are under quarantine and make online purchases within the borders of Turkey or who hold a decision-making position in making purchases. Those between the ages of $0-18$, who are subject to age restriction and are not generally in a decision-making position in purchasing actions, are not included in the study. If the participants are over 65 years of age, they should be in a decision-making position in purchasing actions even if they cannot carry out the relevant action due to the quarantine restrictions. When determining the number of samples in the study, the margin of error was determined to be 0.05 and we aimed to include at least 384 people in the study in total as a result of the calculations. In this context, 460 questionnaires were received in the stage of data collection. The research model was created as in Figure 1, so that the effects between the dimensions could be examined.

Figure 1: Research Model

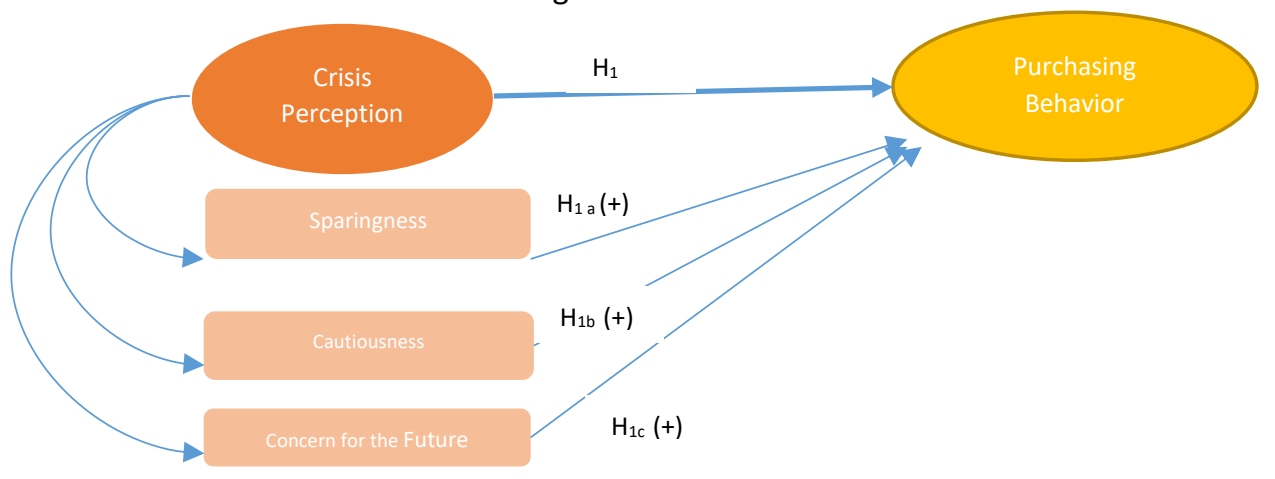




\section{Analysis and Results}

SPSS software was used in the analysis of the data. Before carrying out the analyses, Cronbach's Alpha value, which is an indicator of internal consistency, was calculated to test the reliability of the questionnaires used in the research.

Frequency analysis was carried out to analyze the demographic data. In addition, Friedman tests were used to determine whether there was a statistically significant difference between the variables. KMO and Bartlett's test and Exploratory Factor analysis were implemented to find out how many sub-dimensions were established with the questions about the effect of crisis perception on consumer purchasing behavior in conceptual terms. Also, the statistical reliability and internal consistency of the scales used in the study were ensured by factor analysis. Finally, correlation and multiple regression analyzes were used to test the research hypotheses. The current study has formed one main and three subhypotheses to be tested. A positive and significant relationship between the dependent and independent variables was examined.

\subsection{General Statistics (Frequency Analysis) and Graphics}

The demographic data of 460 participants and frequency analyzes of the answers given by them to multiple-choice questions are presented in Tables 1 and 2.

Table 1: Frequency Distribution of the Demographic Characteristics of Participants

\begin{tabular}{|c|c|c|}
\hline Demographic variable & Number & Percentage \\
\hline \multicolumn{3}{|l|}{ Gender } \\
\hline Female & 221 & 48 \\
\hline Male & 239 & 52 \\
\hline Total & 460 & 100 \\
\hline \multicolumn{3}{|l|}{ Age } \\
\hline $18-25$ & 104 & 22.6 \\
\hline $26-35$ & 209 & 45.4 \\
\hline $34-41$ & 109 & 23.7 \\
\hline $42-49$ & 38 & 8.3 \\
\hline Total & 460 & 100 \\
\hline \multicolumn{3}{|l|}{ Residence } \\
\hline Province & 391 & 85 \\
\hline District & 69 & 15 \\
\hline Total & 460 & 100 \\
\hline \multicolumn{3}{|l|}{ Level of Education } \\
\hline Primary Education & 22 & 4,8 \\
\hline High School & 56 & 12,2 \\
\hline Associate Degree & 21 & 4,6 \\
\hline Undergraduates & 206 & 44,8 \\
\hline Master's Degree & 107 & 23,4 \\
\hline Ph.D. Degree & 48 & 10,4 \\
\hline Total & 460 & 100 \\
\hline \multicolumn{3}{|l|}{ Working Sector } \\
\hline Public & 112 & 24,3 \\
\hline Private Sector & 140 & 30,4 \\
\hline Unemployed & 208 & 45,2 \\
\hline Total & 460 & 100 \\
\hline
\end{tabular}




\begin{tabular}{lcc}
\hline Total Income of the Household & & \\
\hline TRY2500 and below & 39 & 8.5 \\
TRY2501-4000 & 64 & 13.9 \\
TRY4001-5500 & 54 & 11.7 \\
TRY5501-7000 & 78 & 17 \\
TRY7001-8500 & 53 & 11.5 \\
TRY8500 and above & 172 & 37.4 \\
\hline Total & $\mathbf{4 6 0}$ & $\mathbf{1 0 0}$ \\
\hline
\end{tabular}

Table 1 indicated that $48 \%$ of the respondents were male and $52 \%$ were female. Although a large age scale was included in the questionnaire there were no participants over 50 years of age. This was determined to be a negative situation in terms of data as the study contains a part excluded due to age restriction as well. While the majority of the participants have undergraduate or higher education level $(82.7 \%)$, the remaining minority $(17 \%)$ have primary and high school education level. In order to examine the impact of COVID-19 pandemic period on the economic part, the sector question was asked as the first factor to be evaluated, and it was seen that the vast majority of the participants were not working $(45.2 \%)$ and a large part $(30.4 \%)$ were working in the private sector. When asked about the total income obtained in the household, the participants who generated an income of TRY2500 or below were in the minority (8.5\%). The majority of the participants (37.4\%) have an income of TRY8500 or more in the household.

Table 2: Frequency Distribution of Multiple-Choice Questions

\begin{tabular}{lcc}
\hline \multicolumn{1}{c}{ Multiple Choice Question } & No & Percentage \\
\hline Wage Restriction & & 21.3 \\
\hline Yes & 98 & 78.7 \\
No & 362 & $\mathbf{1 0 0}$ \\
\hline Total & $\mathbf{4 6 0}$ & 11.1 \\
\hline Curfew Due to Age & 51 & 89.9 \\
\hline Yes & 409 & $\mathbf{1 0 0}$ \\
No & $\mathbf{4 6 0}$ & 88.3 \\
\hline Total & & 11.7 \\
\hline Curfew Due to Living in a Metropolitan City & 406 & $\mathbf{1 0 0}$ \\
\hline Yes & 54 & $\mathbf{4 6 0}$ \\
\hline Total & & \\
\hline
\end{tabular}

When Table 2 is examined, the vast majority of the participants (78.7\%) did not experience any wage restrictions according to our multiple-choice questions asked to evaluate the economic situation of the participants during the COVID-19 pandemic and to examine their restrictions with regards to shopping. In addition, the majority of the participants $(89.9 \%)$ were not subject to curfew due to age limitations. The reason for this may be that the sample could not include participants over 65 years of age. It was also seen that the vast majority of the participants (88.3\%) lived in the metropolitan areas and were therefore subjected to a curfew. The number of participants who responded as "province" to the question about the place of residence, which was among the demographic questions, was 391 while the number of people subjected to curfews was 406 . This difference may be due to the fact that participants living in the districts of metropolitan cities respond to this question as "district". 


\subsection{Factor Analysis}

Factor Analysis for Crisis Perception Scale During the COVID-19 Pandemic

The present study utilized exploratory factor analysis to test the structural validity of the dataset and model. Prior to interpreting the results of the factor analysis, Bartlett's test of sphericity was used to analyze the suitability of the dataset collected to measure "Crisis Perception During the Covid-19 Pandemic Process" to exploratory factor analysis, and KaiserMayer-Olkin (KMO) to test sampling adequacy.

Table 3: KMO and Bartlett's Test

\begin{tabular}{|c|c|c|}
\hline \multicolumn{3}{|c|}{ KMO and Bartlett's Test } \\
\hline Kaiser-Meyer-Olkin Sampling Adequacy & Measure & 0.876 \\
\hline \multirow[t]{3}{*}{ Bartlett's Test of Sphericity } & Approximate Chi-square & 2006.742 \\
\hline & $\mathrm{Sd}$ & 120 \\
\hline & p significance & 0.000 \\
\hline
\end{tabular}

Accordingly, the adequacy of the dataset collected within the scope of this research was found to be sufficient at a level of KMO:0.876. No variable lower than 0.40 was observed in the Anti-Image Correlation matrix. This indicates that the sampling adequacy of the questions/variables in the crisis perception scale is at the desired level. In addition, Bartlett's test of sphericity was found to be suitable for factor analysis of the dataset at a level of $\mathrm{p}: 0.00$.

Table 4: Crisis Perception Scale Factor Analysis

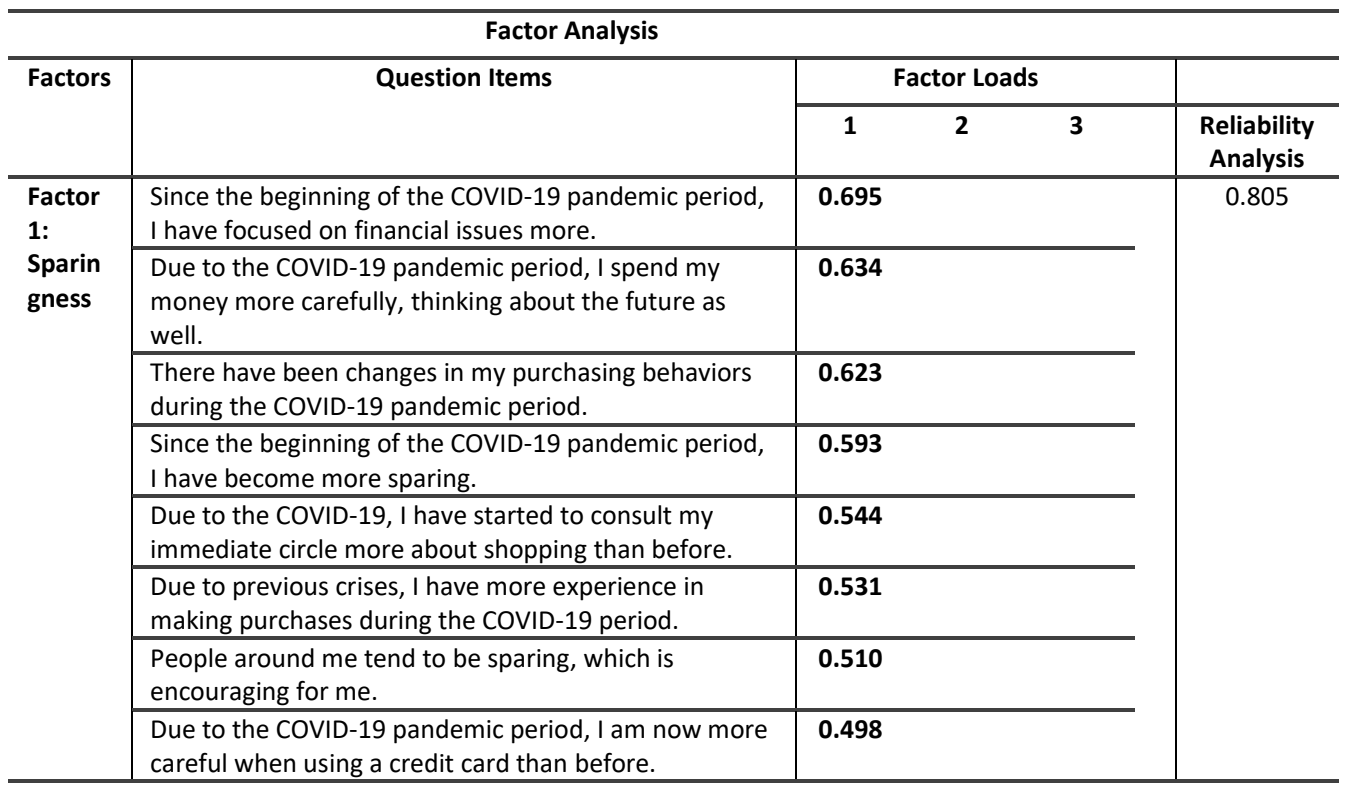




\begin{tabular}{|c|c|c|c|c|c|}
\hline \multirow{4}{*}{$\begin{array}{l}\text { Factor } \\
\text { 2: } \\
\text { Cautio } \\
\text { usness }\end{array}$} & $\begin{array}{l}\text { After the COVID-19 pandemic started, I started buying } \\
\text { less of everything. }\end{array}$ & \multicolumn{3}{|c|}{0.744} & \multirow[t]{4}{*}{0.685} \\
\hline & $\begin{array}{l}\text { The social reflection of the socio-economic situation in } \\
\text { the country puts pressure on me to be more modest in } \\
\text { my spending habits. }\end{array}$ & \multicolumn{3}{|c|}{0.692} & \\
\hline & $\begin{array}{l}\text { During this period, I am obliged to make compulsory } \\
\text { purchases that do not fully meet my needs due to } \\
\text { financial constraints. }\end{array}$ & \multicolumn{3}{|c|}{0.649} & \\
\hline & $\begin{array}{l}\text { Even after the COVID-19 pandemic period has passed, } \\
\text { some of my consumption behaviors will also be } \\
\text { cautious. }\end{array}$ & \multicolumn{3}{|c|}{0.579} & \\
\hline \multirow{4}{*}{$\begin{array}{l}\text { Factor } \\
\text { 3: } \\
\text { Concer } \\
\mathrm{n} \text { for } \\
\text { the } \\
\text { Future }\end{array}$} & $\begin{array}{l}\text { I think the COVID-19 pandemic period in the country } \\
\text { will continue for a long time. }\end{array}$ & & & 0.797 & \multirow[t]{4}{*}{0.745} \\
\hline & $\begin{array}{l}\text { I think my country is in a social and economic crisis } \\
\text { right now. }\end{array}$ & & & 0.761 & \\
\hline & $\begin{array}{l}\text { I am desperate due to the COVID-19 pandemic period } \\
\text { we are experiencing. }\end{array}$ & & & 0.698 & \\
\hline & $\begin{array}{l}\text { Due to the COVID-19 pandemic period we are } \\
\text { experiencing, I do not think the job opportunities will } \\
\text { be good this year. }\end{array}$ & & & 0.692 & \\
\hline \multirow{3}{*}{$\begin{array}{l}\text { Descri } \\
\text { ption } \\
\text { of } \\
\text { Variabi } \\
\text { lity }\end{array}$} & Eigenvalue & 4.706 & 2.295 & 1.084 & \\
\hline & Description Level & $\begin{array}{c}17.89 \\
9\end{array}$ & 17.245 & 15.393 & \\
\hline & Total Description Level & \multicolumn{3}{|c|}{50.536} & \\
\hline
\end{tabular}

* Basic Components Analysis was used as inferential method.

When conducting factor analysis, the variable group consisting of 17 questions to measure the crisis perception was included in the analysis. However, the exploratory factor analysis was modified by removing question 16 "I feel very bad when I cannot meet my needs" from the analysis as it is in a single factor group. According to the results of the exploratory factor analysis:

- In the COVID-19 pandemic period, the question items used to measure the crisis perception were divided into 3 sub-dimensions with eigenvalues greater than 1 . These factors are named as follows: Factor 1: Sparingness: 8 items, factor 2: Cautiousness: 4 items, factor 3: Concern for the Future: 4 items.

- The contribution levels of these factors to measure crisis perception during the Covid-19 period are as follows: Factor 1: Sparingness: $17.8 \%$, factor 2: Cautiousness: $17.2 \%$, factor 3: Concern for the Future: $15.3 \%$

In addition, the level of the total description of variability was determined to be $50.5 \%$.

- Factor loads of the variables in the dimensions formed as a result of factor analysis are as follows:

o Sparingness Dimension factor loads vary between 0.49 and 0.69 ,

o Cautiousness Dimension factor loads vary between 0.58 and 0.74 ,

o Concern for the Future factor loads vary between 0.69 and 0.79 . 
Table 5: Crisis Perception Scale Reliability Coefficients

\begin{tabular}{lcc}
\hline & Number of Variables & \multicolumn{1}{c}{ C. Alpha Coefficient } \\
\hline Sparingness & 8 & 0.805 \\
\hline Cautiousness & 4 & 0.685 \\
\hline Concern for the Future & 4 & 0.745 \\
\hline
\end{tabular}

According to Table 5, the Cronbach Alpha reliability coefficient was used to analyze the internal consistency of the dimensions that are obtained as a result of factor analysis. The reliability coefficients of the dimensions are as follows. Dimensions are generally at a reliable level.

\subsection{Levels of Significance Regarding Factors and Items}

The dimensions related to the scales used in the research and the significance levels regarding the items are presented in Tables 6, 7, and 8. Friedman analyses on Crisis Perception Scale Dimensions during the COVID-19 period are as follows:

Table 6: Levels of Significance Regarding Items About the Dimension of Sparingness

\begin{tabular}{lcc}
\hline Sparingness & Average & $\begin{array}{c}\text { Std. } \\
\text { Deviation }\end{array}$ \\
\hline $\begin{array}{l}\text { 5. Since the beginning of the COVID-19 pandemic period, I have focused on financial } \\
\text { issues more. }\end{array}$ & 3.74 & 1.06 \\
\hline $\begin{array}{l}\text { 6. There have been changes in my purchasing behaviors during the COVID-19 pandemic } \\
\text { period. }\end{array}$ & 4.04 & 0.88 \\
\hline $\begin{array}{l}\text { 7. Due to the COVID-19 pandemic period, I spend my money more carefully, thinking } \\
\text { about the future as well. }\end{array}$ & 3.97 & 0.98 \\
\hline $\begin{array}{l}\text { 8. People around me tend to be sparing, which is encouraging for me. } \\
\text { 9. Due to the COVID-19, I have started to consult my immediate circle more about } \\
\text { shopping than before. }\end{array}$ & 3.53 \\
\hline $\begin{array}{l}\text { 10. Since the beginning of the COVID-19 pandemic period, I have become more sparing. } \\
\text { 11. Due to previous crises, I have more experience in making purchases during the } \\
\text { COVID-19 period. }\end{array}$ & 3.44 \\
\hline $\begin{array}{l}\text { 17. Due to the COVID-19 pandemic period, I am now more careful when using a credit } \\
\text { card than before. }\end{array}$ & 3.11 \\
\hline $\begin{array}{l}\text { Remarks: (i) n=460; (ii) 1: Completely Disagree-5: Completely Agree; (iii) Friedman two-way Anova test Chi-Square: } \\
\text { 728.093, sd: 3, p:0.00 }\end{array}$ & 1.14 \\
\hline
\end{tabular}

Table 6 indicates that the average value for the statement "There have been changes in my purchasing behaviors during the COVID-19 pandemic period" in the dimension of Sparingness of the participants is 4.04 . Therefore, the participants have agreed with this statement at a high level. In addition, the average value of the statement "Due to the COVID19 , I have started to consult my immediate circle more about shopping than before" in this dimension was found to be 2.54 . This indicates that the participants generally disagree with this statement. The dimension of sparingness consists of questions to measure the participants' perception of sparing behavior about saving and purchasing during the COVID-19 period. Following the statement "There have been changes in my purchasing behavior" in this dimension, the statement in which the average is highest is "Due to the COVID-19 pandemic 
period, I spend my money more carefully, thinking about the future as well." This indicates that the participants tend to save money in this process.

Table 7: Levels of Significance Regarding Items About the Dimension of Cautiousness

\begin{tabular}{lcc}
\hline Cautiousness Dimension & Average & $\begin{array}{l}\text { Std. } \\
\text { Deviation }\end{array}$ \\
\hline $\begin{array}{l}\text { 12. After the COVID-19 pandemic started, I started buying less of everything. } \\
\text { 13. The social reflection of the socio-economic situation in the country puts pressure } \\
\text { on me to be more modest in my spending habits. }\end{array}$ & 3.49 & 1.14 \\
\hline $\begin{array}{l}\text { 14. Even after the COVID-19 pandemic period has passed, some of my consumption } \\
\text { behaviors will also be cautious. }\end{array}$ & 3.66 & 0.95 \\
\hline $\begin{array}{l}\text { 15. During this period, I am obliged to make compulsory purchases that do not fully } \\
\text { meet my needs due to financial constraints. (e.g. more affordable product and brand } \\
\text { preference) }\end{array}$ & 3.18 \\
\hline $\begin{array}{l}\text { Remarks: (i) n=460; (ii) 1: Completely Disagree-5: Completely Agree; (iii) Friedman two-way Anova test Chi-Square: } \\
95.201, \text { sd: } 3, \mathrm{p}: 0.00\end{array}$ & 1.15 \\
\hline
\end{tabular}

Table 7 indicates that the average value for the statement "Even after the COVID-19 pandemic period has passed, some of my consumption behaviors will also be cautious" in the dimension of Cautiousness of the participants is 3.66. Accordingly, it is seen that the participants agree with this statement. The low-level average in the cautiousness dimension belonged to the statement "During this period, I am obliged to make compulsory purchases that do not fully meet my needs due to financial constraints." The fact that the average of this statement is 3.18 indicates that participants do not tend to buy compulsorily.

Table 8: Levels of Significance Regarding Items About the Dimension of Concern for the Future

\begin{tabular}{llc}
\hline Concern for the Future Dimension & $\begin{array}{c}\text { Average } \\
\text { Std. } \\
\text { Deviation }\end{array}$ \\
\hline 1. I think my country is currently in a social and economic crisis right now. & 3.79 & 1.26 \\
\hline 2. I think the COVID-19 pandemic period in the country will continue for a long time. & 3.47 & 1.10 \\
\hline 3. I am desperate due to the COVID-19 pandemic period we are experiencing. & 2.78 & 1.13 \\
\hline $\begin{array}{l}\text { 4. Due to the COVID-19 pandemic period we are experiencing, I do not think the job } \\
\text { opportunities will be good this year. }\end{array}$ & 3.84 & 1.05 \\
\hline $\begin{array}{l}\text { Notes: (i) } n=460 ; \text { (ii) 1: Completely Disagree-5: Completely Agree; (iii) Friedman two-way Anova test Chi-Square: } \\
\text { 345.048, sd: 3, p:0.00 }\end{array}$ \\
\hline
\end{tabular}

Table 8 indicates that the average value for the statement "Due to the COVID-19 pandemic period we are experiencing, I do not think the job opportunities will be good this year." in the dimension of Concern for the Future of the participants is 3.84. Accordingly, it is seen that the participants agree with this statement. The fact that the average of the question "I am desperate due to the COVID-19 pandemic period we are experiencing." in this dimension is 2.78 indicates that the participants are not desperate about the process but have expectations about an economic crisis. 


\subsection{Difference Tests}

The analyses evaluating the participants' answers to multiple-choice questions and crisis perception are presented in Tables 9 and 10.

Does the fact that consumers experienced wage restrictions during the COVID-19 period cause them to differ in their crisis perception?

Table 9: Crisis Perception Difference t-Test of Wage Restriction

\begin{tabular}{|c|c|c|c|c|c|c|c|c|c|c|c|c|c|}
\hline \multicolumn{3}{|c|}{ Group Statistics } & & & \multicolumn{4}{|c|}{$\begin{array}{ll}\text { Levene } & \text { t-test } \\
\text { Test } & \end{array}$} & \multirow{3}{*}{$\begin{array}{l}\text { p } \\
\text { (do } \\
\text { uble } \\
\text { que } \\
\text { ue) }\end{array}$} & \multirow{3}{*}{$\begin{array}{l}\text { Avera } \\
\text { ge } \\
\text { Differ } \\
\text { ence }\end{array}$} & \multirow{3}{*}{$\begin{array}{l}\text { Std. } \\
\text { Error } \\
\text { Differ } \\
\text { ence }\end{array}$} & & \\
\hline & \multirow[b]{2}{*}{$\begin{array}{l}\text { Aver } \\
\text { age }\end{array}$} & \multirow[b]{2}{*}{$\begin{array}{l}\text { Std.Dev } \\
\text { iation }\end{array}$} & & & \multirow[t]{2}{*}{$\mathbf{F}$} & & & \multirow[t]{2}{*}{ sd } & & & & \multicolumn{2}{|c|}{$\begin{array}{l}95 \% \\
\text { Confidence } \\
\text { Level } \\
\text { Differences }\end{array}$} \\
\hline & & & & & & & & & & & & $\begin{array}{l}\text { Low } \\
\text { est }\end{array}$ & $\begin{array}{l}\text { Hig } \\
\text { hest }\end{array}$ \\
\hline $\begin{array}{l}\text { I was } \\
\text { subje } \\
\text { cted } \\
\text { to } \\
\text { wage } \\
\text { restri } \\
\text { ction }\end{array}$ & 3.63 & 0.48 & \multirow[t]{2}{*}{$\begin{array}{l}\text { Crisis } \\
\text { Perce } \\
\text { ption }\end{array}$} & $\begin{array}{l}\text { Equal } \\
\text { ity of } \\
\text { Varia } \\
\text { nces }\end{array}$ & $\begin{array}{c}2.6 \\
68\end{array}$ & $\begin{array}{l}.1 \\
03\end{array}$ & $\begin{array}{l}3.4 \\
16\end{array}$ & 458 & .001 & $\begin{array}{c}.2176 \\
0\end{array}$ & $\begin{array}{c}.0637 \\
0\end{array}$ & $\begin{array}{l}.09 \\
242\end{array}$ & $\begin{array}{c}.342 \\
78\end{array}$ \\
\hline $\begin{array}{l}\text { I was } \\
\text { not } \\
\text { subje } \\
\text { cted } \\
\text { to } \\
\text { wage } \\
\text { restri } \\
\text { ction }\end{array}$ & & 0.58 & & $\begin{array}{l}\text { Varia } \\
\text { nces } \\
\text { Not } \\
\text { Equal }\end{array}$ & & & $\begin{array}{l}3.8 \\
10\end{array}$ & $\begin{array}{c}181 . \\
608\end{array}$ & .000 & $\begin{array}{c}.2176 \\
0\end{array}$ & $\begin{array}{c}.0571 \\
1\end{array}$ & $\begin{array}{l}.10 \\
491\end{array}$ & $\begin{array}{c}.330 \\
29\end{array}$ \\
\hline
\end{tabular}

As a result of the t-test carried out to test if consumers' crisis perceptions differ according to whether they are exposed to any wage restriction during the COVID-19 period, it has been determined that wage restriction causes a difference in crisis perception. The averages $(\mu=3.63)$ of consumers who are subjected to wage restrictions and the averages of crisis perceptions $(\mu=3.42)$ of consumers who are not are different from each other. Although public employees did not experience wage restrictions in this process, consumers working in the private sector have faced such a problem. Although the effects of this problem have been tried to be mitigated with state subsidies, the idea that people will not be able to get their former level of income, together with the uncertainty of the COVID-19 pandemic period, has led to an increase in the perception of crisis. As can be seen from the averages, consumers who are subjected to wage restrictions have a higher level of crisis perception.

H2: Being subjected to wage restriction causes a significant difference in the perception of crisis

Does the fact that there are intergenerational differences cause differences in purchasing behavior during the COVID-19 pandemic period 
Table 10: Purchasing Behavior Difference of Generations (ANOVA)

\begin{tabular}{lccccc}
\hline \multicolumn{7}{c}{ ANOVA } \\
\hline Purchasing & Sum of Squares & Sd & Mean Squares & F & p \\
\hline Intergroup & $\mathbf{2 . 9 2 2}$ & $\mathbf{3}$ & .974 & 2.434 & .064 \\
\hline In-group & $\mathbf{1 8 2 . 5 3 0}$ & $\mathbf{4 5 6}$ & .400 & & \\
\hline Total & $\mathbf{1 8 5 . 4 5 2}$ & $\mathbf{4 5 9}$ & & & \\
\hline
\end{tabular}

According to the results of the Anova test carried out to determine whether the purchasing behavior during the COVID-19 period differs according to the intergenerational difference $(F=2,434$ and $p=0.064)$, no significant difference was determined between generations. Therefore, the $\mathrm{H} 3$ hypothesis was rejected. When the studies evaluating the intergenerational difference and purchasing behavior in the literature were examined, such a difference was found, and it was divided into young and elderly groups. While the younger group continued their consumption, the elderly group's consumption decreased (Urbonavicius and Pikturniene, 2010). Contrary to these results, the result of the present study is that there is no such difference. The reason for this is that all generations involved in the process do not have experience of a crisis with these characteristics and on such a scale.

\subsection{Correlation and Regression Analysis}

In this part of our study, Pearson Correlation analysis was used to determine the relationship between the sub-factors of the scales used in the questionnaire form and the results are presented in Table 11.

Table 11: Correlation Analysis of the Sub-Dimensions of the Scales Used in the Research Model

\begin{tabular}{|c|c|c|c|c|c|c|}
\hline & & Sparingness & Cautiousness & $\begin{array}{l}\text { Concern for } \\
\text { the Future }\end{array}$ & $\begin{array}{l}\text { Crisis } \\
\text { Perception }\end{array}$ & $\begin{array}{l}\text { Purchasing } \\
\text { Behavior }\end{array}$ \\
\hline Sparingness & $\begin{array}{l}\text { Pearson } \\
\text { Correlation }\end{array}$ & 1 & & & & \\
\hline Cautiousness & $\begin{array}{l}\text { Pearson } \\
\text { Correlation }\end{array}$ & $0.606^{* *}$ & 1 & & & \\
\hline $\begin{array}{l}\text { Concern for the } \\
\text { Future }\end{array}$ & $\begin{array}{l}\text { Pearson } \\
\text { Correlation }\end{array}$ & $0.179^{* *}$ & $0.165^{* *}$ & 1 & & \\
\hline Crisis Perception & $\begin{array}{l}\text { Pearson } \\
\text { Correlation }\end{array}$ & $0.772^{* *}$ & $0.784^{* *}$ & $0.652^{* *}$ & 1 & \\
\hline $\begin{array}{l}\text { Purchasing } \\
\text { Behavior }\end{array}$ & $\begin{array}{l}\text { Pearson } \\
\text { Correlation }\end{array}$ & $0.656^{* *}$ & $0.640^{* *}$ & $0.169^{* *}$ & $0.643^{* *}$ & 1 \\
\hline
\end{tabular}

Table 11 indicates that there is a positive significant relationship between crisis perception and purchasing behavior $(r=0.643, p<0.01)$. The change in consumer perceptions with the crisis is also effective in consumers' purchasing behaviors (Leinwand et al., 2008; Amalia and lonut, 2009; Flatters and Willmott, 2009; Nistorescu and Puiu, 2009; Salzman and O'Reilly, 2010; Retail, 2010; Mansoor and Jalal, 2011; Cánovas et al. Ibañez, 2012; Petev et al., 2012; Zhigalova, 2012; Pandelica et al., 2013; Kaytaz and Gül, 2014; Petev and Franches, 2014). These findings imply that the participants increased their purchasing behavior in contrast to the known economic crises during the COVID-19 period. The fact that the COVID-19 period did not start as an economic crisis but as a pandemic can be the reason for this. This suggests 
that the consumers, who have decreased their spending in physical contexts of life such as social activities or formal education due to the pandemic, direct their purchasing habits to other expenses with the feeling of pressure or restriction.

The evaluation of this relationship in terms of sub-dimensions indicates that there is a positive significant relationship between purchasing behavior and sparingness $(r=0.656$, $p<0.01)$, cautiousness $(r=0.640, p<0.01)$ and concern for the future $(r=0.169, p<0.01)$, which are the sub-dimensions of crisis perception scale.

Table 12: Crisis Perception Dimensions for the duration of Covid-19 on Purchasing Behavior

\begin{tabular}{l|l|lllllll}
\hline $\begin{array}{l}\text { Dependent } \\
\text { Variable }\end{array}$ & $\begin{array}{l}\text { R2/ } \\
\text { Corrected R2 }\end{array}$ & $\begin{array}{l}\text { Independent } \\
\text { Variable }\end{array}$ & $\boldsymbol{\beta}$ & Std. Error & $\mathbf{t}$ & $\mathbf{p}$ & $\mathbf{F}$ & $\mathbf{p}$ \\
\hline $\begin{array}{l}\text { Purchasing } \\
\text { Behavior }\end{array}$ & $0.524 / 0.521$ & Fixed Variable & & .128 & 8.144 & .000 & 167.482 & .000 \\
\cline { 3 - 8 } & & Sparingness & .419 & .038 & 10.273 & .000 & \\
\cline { 3 - 8 } & & Cautiousness & .381 & .034 & 9.371 & .000 & .343 \\
\cline { 3 - 8 } & & $\begin{array}{l}\text { Concern for } \\
\text { the Future }\end{array}$ & .031 & .024 & .950 & .343 \\
\hline
\end{tabular}

Table 12 indicates that the model was quite significant $(F=167.482 p=0.000, R 2=0.524)$. Sparingness $(\beta=0.419 p<0.01)$, one of the independent variables in the model, was determined to have a positive effect on purchasing behavior and the $\mathrm{H} 1 \mathrm{a}$ hypothesis was accepted within the framework of these findings $(p<0.01)$. Another independent variable, cautiousness $(\beta=0.381, p<0.01)$, was found to have a positive effect on purchasing behavior and the $\mathrm{H} 1 \mathrm{~b}$ hypothesis was accepted within the framework of these findings. It was observed that the last independent variable, concern for the future $(\beta=0.031, p<0.01)$ did not have a significant effect on purchasing behavior. The $\mathrm{H} 1 \mathrm{c}$ hypothesis was rejected $(p>0.01)$ in accordance with this assessment.

Table 13: The Impact of Crisis Perception on Purchasing Behavior During the COVID-19 Process

\begin{tabular}{l|l|lllllll}
\hline $\begin{array}{l}\text { Dependent } \\
\text { Variable }\end{array}$ & $\begin{array}{l}\text { R2/ } \\
\text { Corrected R2 }\end{array}$ & $\begin{array}{l}\text { Independent } \\
\text { Variable }\end{array}$ & $\boldsymbol{\beta}$ & $\begin{array}{l}\text { Std. } \\
\text { Error }\end{array}$ & $\mathbf{t}$ & $\mathbf{p}$ & $\mathbf{F}$ & $\mathbf{p}$ \\
\hline Purchasing & $0.414 / 0.412$ & Fixed Variable & & 0.141 & 7.441 & 0.00 & 323.177 & $0.00^{\mathrm{b}}$ \\
\cline { 2 - 9 } Behavior & & Sparingness & 0.643 & 0.040 & 17.977 & 0.00 & & \\
\hline
\end{tabular}

Table 13 indicates that the significance of the model is achieved once again as in the previous table. Crisis perception $(\beta=0.643, p<0.01)$, an independent variable in the model, was determined to have a positive effect on purchasing behavior. Within the framework of these findings, the $\mathrm{H} 1$ hypothesis, which is the main hypothesis of the study, was partially accepted.

The overall assessment of all the hypotheses of the research is summarized in Table 14 and some of the results are consistent with the findings in the literature.

Table 14: Hypothesis Results in the Context of the Research Model

\begin{tabular}{cll}
\hline Hypotheses & Result & Analysis \\
\hline H1 & Partially Accepted & Regression \\
\hline H2 & Accepted & t-test \\
\hline H3 & Rejected & Anova \\
\hline
\end{tabular}




\section{Discussion}

This study provides an overview of how the perception of economic crisis that emerges with the COVID-19 pandemic period affects purchasing behaviors of consumers and the results concerning whether the concept of wage restriction, that consumers from different generations are subjected to, causes a significant difference.

Similar to previous studies in the literature (Murrugarra and Signoret 2002; Leinwand et al., 2008; Berber, 2009; Flatters and Willmott, 2009; Nistorescu and Puiu, 2009; Retail, 2010; Mansoor:2011; Zhigalova, 2012; Kaytaz and Gül, 2014), the present study emphasized that the perception of economic crisis has a significantly positive effect on consumers' purchasing behaviors. In contrast to the known economic crises, consumers responded to such a comprehensive crisis that they encountered for the first time by preferring another method (e-commerce) rather than consumption reduction. This aspect of the study differs from previous studies on crisis and purchasing behavior or consumer behavior. In addition, the crisis perception, which emerged with the limitations in social and economic life during the COVID-19 pandemic period as a new phenomenon and influenced the whole world, has affected consumer purchasing behaviors.

Hasan, Islam and Doza (2021) conducted a study on the consumers located at India, Bangladesh, and Pakistan and revealed a difference in perception of the COVID-19 crisis of the people of these three countries as well as their consumption patterns due to their perception of the pandemic.

The crisis perception scale used in the study was divided into 3 factors as a result of factor analysis. The first of these factors is the sparingness. There are studies examining the effect of sparingness on consumer purchasing behavior (Ang, Leong and Kotler 2000; Leinwand et al., 2008; Amalia and Ionut, 2009; Berber, 2009; Booz; Company; 2009; Nie et al., 2010; Retail, 2010; Dutt and Padmanabhan 2011). As a result of the analysis, the present study determined that the sparingness of consumers during the COVID-19 pandemic period had a positive significant effect on purchasing behavior. The consumers' exposure to economic restrictions such as wage restrictions during the COVID-19 period, their irrational and excessive behavior in their purchases during such times of panic and uncertainty have caused them to be particularly sparing about the price. Therefore, consumers behaved in a sparing manner in other consumption areas by spending more on compulsory consumption products. Similarly, although the consumers showed a mental tendency to be sparing, they have continued to make purchases for their activities due to long periods of quarantine.

There are some studies in the literature on the effect of cautiousness, the second factor of the scale, on consumer purchasing behavior (Amalia and lonut, 2009), Pop and Rosca, 2009 Nistorescu and Puiu, 2009; Kang and Sawada (2008 Retail, 2010: Murrugarra and Signoret (2002; Ang (2000: Dutt and Padmanabhan (2011) McKenzie and Schargrodsky (2005, 2011). The effect of the cautiousness on purchasing behaviors during the COVID-19 pandemic period was determined to be significantly positive in this study. The uncertainty in economic, health

and social life caused by the COVID-19 pandemic period and the unpredictability of its ending have led consumers to be more cautious in their purchasing behaviors.

The literature includes some studies on the effect of concern for the future, the last factor of the scale, on consumer purchasing behaviors (Katona, 1974; McKenzie, 2003; Drakopoulos, 2008; Perner, 2008; Pop and Rosca, 2009; Voinea and Filip, 2011). The present study 
determined that the sub-dimension of concern for the future in consumers during the COVID19 pandemic period did not have a positive significant effect on the purchasing behavior. The fact that people faced such a global health crisis for the first time can be the cause of rejection of the hypothesis while the positive discourses of the managers indicating that the process would be overcome with measures and precautions and the continuous studies to find vaccination in the field of healthcare to treat the pandemic have prevented consumers from having any concern about the future. In addition, the explanations implying that steps will be taken to normalize the process within the country have created a positive perception for the consumers.

The pandemic brought about an economic crisis in all countries and most of the small and medium-sized enterprises were shut down. Therefore, unemployment rates peaked in Turkey and around the world. People have had to become more sparing and abandon some of their consumption habits. Demand for goods other than necessity goods has decreased and people have tried to meet their priority needs by making adjustments in their expenditures (Kayabaşı, 2020). In other words, individuals had to change their purchasing behavior due to salary restrictions, which was effective in perceiving the pandemic as a crisis.

One of the restrictions enforced in the pandemic process in Turkey, which constitutes the field of application of the study, was wage restrictions. This restriction was determined to cause a significant difference in the perception of crisis by asking consumers whether they are subjected to wage restrictions as the present study is related to the perception of economic crisis. The fact that economic crises affect the spending habits of individuals by nature supports the fact that wage restrictions also have a direct impact on the perception of crisis.

In their study, Urbonavicius and Pikturniene (2010) have determined that purchasing behaviors changed across generations. It was analyzed whether there was a significant difference in purchasing behavior of generations within the scope of the study, but there was no significant difference between generations in that regard. The reason for this can be the lack of changes in the responses of generation $Z$ and the limited number of participants over the age of 65 in the survey, especially since this is the first-time generation $Z$ has faced such a global crisis.

The study conducted by Hasan, Islam, and Doza (2021) show that consumers' perception of the crisis during the Covid-19 period, and the resulting consumption patterns differ with participants' age. Their study also revealed that the perception of crisis between generations did not create significant differences in purchasing behavior. The reason for this difference between the studies may be due to their participants who are citizens of different countries and the socio-cultural structures of these countries.

As a result, this study revealed to what extent the crisis perception of consumers has affected their purchasing behaviors in Turkey during the COVID-19 pandemic period. The application of the same study in other countries may lead to different results. The reason why the results show similarities and differences compared to the literature is that the related country's socio-cultural and economic structure, policies enforced during the pandemic process, the discourses and sanctions of the leaders and managers in the process are among the most important factors on the consumers' perception. 


\section{Conclusion}

The most important phenomenon in a crisis environment is the consumer purchasing behavior that emerges depending on the crisis perception of the consumers.

According to the findings obtained as a result of the present study, the following evaluations were carried out.

The crisis perception scale used in the study was divided into 3 factors as a result of factor analysis. With this scale, consumers' perception of this crisis was determined in the Covid-19 process. At the same time, the businesses have been shown how much the consumers were affected by the concepts of sparingness, cautiousness, and concern for the future. Based on the sample selected as a result of factor analysis, this scale describes $50.5 \%$ of the concept of sparingness $17.2 \%$ of the concept of cautiousness, and $15.3 \%$ of the concept of concern for the future.

In order to measure the reliability of the research scale and its competence in measuring concepts, reliability analysis was performed on the main and sub-dimensions of the scale. According to the results obtained from this analysis, they were found to be generally reliable.

In order to reveal the levels of agreement of the participants with the statements of the scale created for the implementation part of the study, Friedman test was conducted, and the agreement levels were compared. The results obtained in this regard are as follows:

During the COVID-19 period, participants stated that they did not experience any change in consulting their immediate circle about shopping, but they experienced changes related to purchasing behavior.

In contrast to the known economic crises, the participants stated that they did not make compulsory purchases during the COVID-19 period, but they displayed a cautious consumption behavior.

These two conditions point out that consumers generally exhibited behaviors characterized by a rational choice during the Covid-19 pandemic, as they did in many crises, and expressed that they made purchases that would provide the maximum level of benefit. In the rational choice theory, consumers rely on the "benefit" factor when making a purchase. The rational consumer chooses goods that will provide the highest benefit for them within their limited budget. The main purpose of this type of consumer is to maximize benefit (Dal and Korkmaz , 2020: 72). Consumers try to make arrangements in their purchasing behavior due to the economic fluctuations they are experiencing or likely to experience during periods of crisis. The important concept is to be behave cautiously rather than spend or save resources. In this way, the consumers can protect themselves from the significant effects of a crisis and have the highest benefit with the financial resources they possess. (Hayta, 2012: 19). The attitude of the consumers in the Covid-19 pandemic tends to be more rational, just like in a period of economic crisis. By trying to foresee potential problems related to business and financial opportunities after a pandemic, the consumer strives to obtain maximum benefit with the limited resources at their disposal.

They stated that the COVID-19 pandemic period did not lead them to have despair about their future, and they expressed their concern for job opportunities. Based on these findings, although the COVID-19 pandemic period started as a health crisis, it also brought about a social and economic crisis due to the quarantines experienced and the closed workplaces for this reason. When we examine whether the COVID-19 pandemic is evaluated as a known 
economic crisis, we see that it is not very suitable for this. Participants' health and psychological concerns, rather than economic concerns, prevent consumers from responding to known economic crises.

The correlation analysis determined that the relationship between crisis perception and purchasing behavior during the COVID-19 period is positive, moderate, and significant. This relationship is negative in known economic crises, but the structure of the economic crisis that emerged during the COVID-19 pandemic period differs from others found in the literature. The fact that consumers are intensively at home, experiencing deductions in road, education, and other social expenses due to quarantines has created a budget that they can allocate to other expenditures. In particular, the consumers, who spend most of their day on social media or in contact with electronic devices where advertisements are presented rigorously, have ensured that the budget created by the compulsory deductions is channeled towards online shopping. The $\mathrm{H} 1$ hypothesis established for all these reasons was also supported by the answers given by the participants.

As a result of the regression analysis, the sparingness and cautiousness had a significant effect on purchasing behavior, however, concern for the future did not have a significant effect. The COVID-19 pandemic is the first health crisis that people living in this era face globally. Unlike other crises, it was supposed that this crisis would not last long, so the consumers would not get the perception of being sparing and cautious. A correlation between concern for the future and purchasing behavior of consumers was determined to be low as a result of the correlation analysis and it was not determined to have an effect on purchasing behavior in regression analysis. Having encountered a type of crisis that even the previous generation has not seen, the consumers are so greatly focused on ending the process that they do not show a related reaction. The use of short-term criteria for the ending of the pandemic process in the statements of the authorities can also be the basis for the absence of concern for the future. The result may be different with repeating the application in this period when it is explained that the crisis is in a structure that will last for years. This comparison should be taken into account in future studies. In addition, the high level of household income of the participants and the case of employment in an industry group that does not face problems such as wage restrictions in this process are also factors affecting concern for the future. This type of costumers attaches more importance to the psychological situation they will have during the process rather than the financial problems they will experience. For this reason, the effects of sparingness and cautiousness on purchasing behavior are thought to be positive. In future studies, the general inclusion of the segment that is materially affected by the process in the sampling can change the directions of these effects.

This study mainly highlights the impact of crisis perception caused by the COVID-19 period on consumer purchasing behaviors. The present study also provided an overview of the COVID-19 period from a consumer perspective. The study contributed to the literature by addressing the perception of economic crisis and the pandemic period.

The current study contributed to the literature on COVID-19 with a particular focus on consumer behavior. Investigating the characteristics of consumers' purchasing behavior during COVID-19, this study revealed how the perception of a crisis affects the purchasing behavior of consumers and provides potential clues in making effective marketing decisions and creating business related strategies. 
The measures, policies, and decisions of governments, in particular, during the Covid-19 pandemic are effective in shaping individuals' perception in society. Since the way individuals perceive the process as a crisis also affects their purchasing behavior, successful management of this process is crucial for the sustainability of the businesses in society and of the economic system. In this context, the results of the present study present valuable information for policy makers and producers of goods/services to make consumer-oriented decisions.

\section{Limitations and Directions for Future Research}

This study is limited in some ways. One of the problems encountered when conducting the survey, which constitutes the application part of the research, is that it has to be carried out only in an online environment due to quarantine. For this reason, it was not possible to reach the consumers over the age of 65 , who are the most heavily affected group of the pandemic process, and those consumers over the age of 65 who were reached did not prefer or could not do the online survey. In addition, if the questions, which are one of the positive aspects of the face-to-face questionnaire, are not understood, some questions that have been deprived of further explanation have therefore been excluded from the analysis. As we mentioned earlier, the COVID-19 pandemic period is the first crisis experienced by the consumers living in this era on such a global scale and it is also a crisis with psychological effects due to stagnation of social life and high number of deaths. Unlike known economic crises, consumers have tried to look for opportunities to comfort and make themselves happy rather than looking for financial protection and have not reacted to it as an economic crisis. All these reasons also cause the scales created for the known economic crises not to explain this process in all aspects. Considering that this process will take years and even then, the world may encounter such health crises, it is necessary to develop a crisis perception scale to be used in this field. 


\section{References}

Ahorsu, D.K.; Lin, C.-Y.; Imani, V.; Saffari, M.; Griffiths, M.D.; Pakpour, A.H. (2020), "The fear of COVID-19 scale: development and initial validation", International journal of mental health and addiction, 1-9.

Ali, B. J. (2020), "Impact of COVID-19 on consumer buying behavior toward online shopping in Iraq", Economic Studies Journal, Vol.18, No.42:267-280.

Amalia, P.; lonut, P. (2009), "Consumers' reaction and organizational response in crisis context." The Journal of the faculty of Economics, Vol. 1, No.5: 779-782.

Ang, S. H. (2000), "Personality influences on consumption: insights from the Asian economic crisis", Journal of International Consumer Marketing, Vol.13, No.1: 5-20.

Ang, S. H. (2001), "Crisis marketing: A comparison across economic scenarios", International Business, Vol. 10: 263-284.

Ang, S. H.; Leong, S. M.; Kotler, P. (2000), "The Asian apocalypse: Crisis marketing for consumers and business", Long Range Planning, Vol. 33: 97-119

Arora, N.;Charm, T.;Grimmelt, A.;Ortega, M.;Robinson, K.;Sexauer, C.;Yamakawa, N. (2020), “A global view of how consumer behavior is changing amid COVID-19", Mcknsey and Company. April.

Asioli, D.; Aschemann-Witzel, J.; Caputo, V.; Vecchio, R.; Annunziata, A.; Næs, T.; Varela, P. (2017), "Making sense of the "clean label" trends: A review of consumer food choice behavior and discussion of industry implications", Food Research International, Vol.99: 58-71.

Baker, S. R.; Farrokhnia, R. A.;Meyer, S.; Pagel, M.; Yannelis, C. (2020), "How does household spending respond to an epidemic? Consumption during the 2020 COVID-19 pandemic", The Review of Asset Pricing Studies, Vol.10, No.4: 834-862.

Bakkar, M. (2020), "The Effect of COVID-19 Spread on Egyptian consumer behavior", Available at http://dx.doi.org/10.2139/ssrn.3673931

Berber, Ş. G. (2009), An appraisal on customer consuming behavior during economic crisis. (Master thesis), Marmara University, İstanbul

Cánovas, A.; Ibañez, I. (2012), The Changes on the Spanish Consumer Behaviour After rhe Financial Crisis 2007: Applied towards a switch to store branded products.

Chauhan, V.; Shah, M. H. (2020), "An Empirical Analysis into Sentiments, Media Consumption Habits, and Consumer Behaviour during the Coronavirus (COVID-19) Outbreak", Purakala with ISSN, 0971-2143.

Chenarides, L.; Grebitus, C.;Lusk, J. L.; Printezis, I. (2021), "Food consumption behavior during the COVID-19 pandemic", Agribusiness, Vol. 37, No.1: 44-81.

Dal, N. E.; Korkmaz, İ. (2020). Tüketim ve Tüketim ile ilgili kavramlar. M. B. Nakıboğlu içinde, Güncel Pazarlama Çalışmaları (s. 49-80). Ankara: Akademisyen Kitabevi.

Drakopoulos, S. (2008), "The paradox of happiness: towards an alternati; explanation", Journal of Happiness Studies, Vol. 9, No. 2: 303-315.

Dutt, P.; Padmanabhan, V. (2011), "Crisis and consumption smoothing", Marketing Science, Vol.30, No.3: 491-512

Ellison, B.;McFadden, B.;Rickard, B. J.; Wilson, N. L. (2021), "Examining Food Purchase Behavior and Food Values During the COVID-19 Pandemic", Applied Economic Perspectives and Policy, Vol.43,No.1:5872.

Erol,M (2010). Ekonomik Kriz ve KOBi'ler. Girişimcilik ve Kalkınma Dergisi, Vol. 5, No,1.,165-181.

Fernandes, N. (2020), "Economic Effects of Coronavirus Outbreak (COVID-19) on the World Economy", IESE Business School Working Paper No. WP-1240-E, Available at http://dx.doi.org/10.2139/ssrn.3557504 
Fiszbein, A.; Adúriz, I.; Giovagnoli, P. I. (2003), "The Argentine crisis and its impact on household welfare" CEPAL Review, Vol. 79, April.

Flatters, P.; Willmott, M. (2009), "Understanding the post-recession consumer", Harvard Business Review, Vol.87, No.7/8:106-112.

Grashuis, J.; Skevas, T.; Segovia, M. S. (2020), “Grocery Shopping Preferences during the COVID-19 Pandemic", Sustainability. Vol. 12, No. 13:5369.

Hasan, S.; Islam, M. A.; Bodrud-Doza, M. (2021), "Crısıs perceptıon and consumption pattern durıng Covid-19: Do demographic factors make difference?", Heliyon, 7,1-11.

Hayta, A. B. (2012). Ekonomik Krizin Tüketici Satın Alma Davranışı Üzerindeki Etkileri. M. Babaoğul, A. Şener, \& E. B. Buğday içinde, Tüketici Yazıları 3. Ankara: Hacettepe Üniversitesi Tüpadem.

Hutchins, H. M. (2008). What Does HRD Know About Organizational Crisis Management? Not Enough! Read On., Advances in Developing Human Resources, Vol. 10, No. 3., 299-309.

Kang, S. J.; Sawada, Y. (2008), "Credit crunch and household welfare: The case of the Korean financial crisis", The Japanese Economic Review, Vol.59, No.4: 438-458.

Katona, G. (1974), "Psychology and Consumer Economics", Journal of Consumer Research, Vol.1:1-8.

Kayabaşı, T. E. (2020), "COVID-19'un piyasalara ve tüketici davranışlarına etkisi”, Avrasya Sosyal ve Ekonomi Araştırmaları Dergisi, 7(5). 15-25.

Kaytaz, M.; Gul, M. C. (2014), "Consumer response to economic crisis and lessons for marketers: The Turkish experience". Journal of Business Research, Vol.67, No.1:2701-2706.

Krishnamurthy, A.; Gopinath, K. S. (2020), "The need for prioritizing cancer surgeries amidst the COVID-19 pandemic", Indian J Surg Oncol, Vol.11:169-170.

Kursan Milaković, I. (2021), "Purchase experience during the COVID-19 pandemic and social cognitive theory: The relevance of consumer vulnerability, resilience, and adaptability for purchase satisfaction and repurchase", International Journal of Consumer Studies, 1-18.

Laato, S.; Islam, A. N.; Farooq, A.; Dhir, A. (2020), "Unusual purchasing behavior during the early stages of the COVID-19 pandemic: The stimulus-organism-response approach", Journal of Retailing and Consumer Services, Vol. 57, 102224.

Leinwand, P.; Moeller, L. H.; Shriram, K. B. (2008), Consumer Spendings in the Economic downturn: The Wide-Ranging Impact on Consumer Behavior. Retrived November 23, 2010.

Lokshin, M. M.; Yemtsov, R. (2004), "Household strategies of coping with shocks in post-crisis Russia", Review of Development Economics, Vol.8, No.1: 15-32.

Mander, J. (2020), "Coronavirus: Latest Consumer Trends, Impact \& Reaction. GWI" https://blog.globalwebindex.com/trends/coronavirus-and-consumers/.

Mansoor, D.; Jalal, A. (2011), "The global business crisis and consumer behavior: Kingdom of Bahrain as a case study", International Journal of Business and Management, Vol.6, No.1: 104-115.

McKenzie, D.; Schargrodsky, E. (2005), "Buying less, but shopping more: Changes in consumption patterns during a crisis", In: Bureau for Research and Economic Analysis of Development (BREAD), Vol. 92, (Working Paper).

McKenzie, D.; Schargrodsky, E. (2011), "Buying less but shopping more: The use of nonmarket labor during a crisis", Journal of LACEA Economia, Vol.11, No.2: 1-35

Mehrolia, S.; Alagarsamy, S.; Solaikutty, V. M. (2020), "Customers response to online food delivery services during COVID-19 outbreak using binary logistic regression", International Journal of Consumer Studies, 1- 13. https://doi.org/10.1111/ijcs.12630

Murrugarra, E.; Signoret, J. (2002), Vulnerability in consumption, education and health: Evidence from Moldova during the Russian crisis. Mimeo, Washington, DC: World Bank. 
Nie, B.; Zhao, F.; Yu, J. (2010), The impact of the financial crisis on consumer behaviour and the implications of retail revolution. In Marketing Science Innovations and Economic Development: Proceedings of 2010 Summit International Marketing Science and Management Technology Conference.

Nistorescu, T.; Puiu, S. (2009), Marketing strategies used in crisis-study case, MPRA Paper 17743, University Library of Munich, Germany.

Noordegraaf-Eelens, L.; Franses. P. H. (2014), Does a financial crisis make consumers increasingly prudent?, Econometric Institute Report, 2014-16.

Odabaşı, Y. Küresel Kriz Ortamında Tüketici Davranışları. Tüketici Yazıları (II), 67.

Odabaşı, Y.; Barış, G. (2013), Tüketici davranışı (13. baskı), İstanbul: MediaCat Yayınları.

Pandelica, A., Didea, I.; Diaconu, M. (2013), “Are You Panicked? Economic And Health Consequences Of The Economic Crisis: A Psychological Approach In Romanian Context", Scientific Bulletin-Economic Sciences, Vol.12, No.1: 39-49.

Pathak, G.; Warpade, S., (2020), "Impact of Lockdown Due to COVID-19 on Consumer Behaviour While Selecting Retailer for Essential Goods", Zeichen, Vol.6, No.7: 282-289.

Patil, B.; Patil, N. (2020), Impact of Covid 19 Pandemic on Cosnumer Behaviour. Mukt Shabd Journal,vol. 9, No.5:3074-3085

Peng, N.;Chen, A. (2021), "Consumers' Luxury Restaurant Reservation Session Abandonment Behavior During the COVID-19 Pandemic: The Influence of Luxury Restaurant Attachment, Emotional Ambivalence, and Luxury Consumption Goals", International Journal of Hospitality Management, Vol. 94, 102891.

Perner, L. (2008), "Consumer behaviour: the psychology of marketing; Uni. of Southern California", [Online] Available: http://www.consumerpsychologist. Com, (Haziran 20, 2020).

Perriman, H. E.; Ramsaran-Fowdar, R. R.; Baguant, P. (2010), The impact of the global financial crisis on consumer behaviour. The 2010 Annual London Business.

Petev, I.; Pistaferri, L.; Eksten, I. S. (2012), Consumption in the great recession. The Russell Sage Foundation and the Stanford Center on Po;rty and Inequality, 2-3.

Pop, D.; Rosca, D. (2009). Impact of economic and financial crisis on individual consumer behaviour. Annals of Oradea Uni;rsity, Faculty of Engineering and Technology Management. vol. 8.

Prentice, C.; Quach, S.; Thaichon, P. (2021), "Antecedents and consequences of panic buying: The case of COVID-19", International Journal of Consumer Studies, 1-15. https://doi.org/10.1111/ijcs.12649

Retail, K (2010), The New Consumer Behavior Paradigm: Permanent or Fleeting?, PriceWaterhouseCoopers.

Richardson, N. J.; MacFie, H. J. H.; Shepherd, R. (1994), “Consumer attitudes to meat eating”, Meat Science, Vol.36, No.1-2: 57-65.

Salzman, M.; O'Reilly, A. (2010), Trends in Mindful Consumption. Worldwide Knowledge Exchange.

Sayyida, S.; Hartini, S.; Gunawan, S.; Husin, S. N. (2021), "The Impact of the Covid-19 Pandemic on Retail Consumer Behavior", Aptisi Transactions on Management (ATM), Vol.5, No.1:79-88.

Shao, C. (2009), "The Impact of Financial Crisis on Consumer Buying Behavior", Marketing Management Garden, No.6

Sharma, V.; Sonwalkar, J. (2013). "Does consumer buying behavior change during economic crisis?". International Journal of Economics \& Business Administration, 1(2), 33-48

Sheth, J. (2020), "Impact of Covid-19 on consumer behavior: Will the old habits return or die?", Journal of Business Research, Vol.117: 280-283. 
Stanciu, S.; Radu, R. I.; Sapira, V.; Bratoveanu, B. D.; Florea, A. M. (2020), "Consumer Behavior in Crisis Situations. Research on the Effects of COVID-19 in Romania", Annals of the University Dunarea de Jos of Galati: Fascicle: I, Economics \& Applied Informatics, Vol.26, No.1.

Stephany, F.; Stoehr, N.; Darius, P.; Neuhäuser, L.; Teutloff, O.; Braesemann, F. (2020), "The CoRiskIndex: A data-mining approach to identify industry-specific risk assessments related to COVID-19 in realtime", arXiv preprint arXiv:2003.12432.

Sumarto, S.; Wetterberg, A.; Pritchett, L. (1999), The social impact of the crisis in Indonesia: results from a nationwide Kecamatan survey. East Asia Environment and Social Development Unit [World Bank].

Tam, B. (2020), How Covid-19 will change consumer behavior p purchase patterns. hillpknowlton strategies. $\quad$ https://www.hkstrategies.com/how-covid-19-will-changeconsumer-behavior-purchasepatterns/.

Urbonavicius, S.; Pikturniene, I. (2010), “Consumers in the face of economic crisis: Evidence from two generations in Lithuania", Economics and Management, Vol. 15:827-834.

Voinea, L.; Filip, A. (2011), "Analyzing the main changes in new consumer buying behavior during economic crisis", International Journal of Economic Practices and Theories, Vol.1, No.1: 14-19.

Wang, E.; An, N.; Gao, Z.; Kiprop, E.; Geng, X. (2020), "Consumer food stockpiling behavior and willingness to pay for food reserves in COVID-19", Food Security, , Vol.12, No.4: 739-747

Wise, T.; Zbozinek, T. D.; Michelini, G.; Hagan, C. C.; Mobbs, D. (2020, March 19), Changes in risk perception and protective behavior during the first week of the COVID-19 pandemic in the United States. https://doi.org/10.31234/osf.io/dz428

Wright, O.; Blackburn, E. (2020), "How Covid-19 will permanently change consumer behavior", Accenture. https://www.accenture.com/_acnmedia/PDF-123/Accenture-COVID19-Pulse-SurveyResearch-PoV.pdf\#zoom $=40$

Yadav, A.; Kumar, P. (2021), "Impact of Covid-19 on Consumers' Essentıal Buying Behavior-an Indian Perspective", International Journal of Management (IJM), Vol.12, No.1.

Yendamuri, P.; Keswakaroon, D.; Lim, G. (2020), “How Covid-19 Is Changing Southeast Asia's Consumers", https://www.bain.com/insights/how-covid-19-is-changing-southeast-asias-consumers/. (Accessed 18 June 2021).

Zhigalova, A. (2012), Shifting of Consumer Behaviour. European Integration and Baltic Sea Region Studies, 2. University-Business Partnership through the Triple Helix Approach (2011) 91.

Zurawicki, L.; Braidot, N. (2005), "Consumers during crisis: Responses from the middle class in Argentina", Journal of Business Research, Vol. 58, No.8: 1100-1109.

Zwanka, R. J.; Buff, C. (2021), "COVID-19 generation: a conceptual framework of the consumer behavioral shifts to Be caused by the COVID-19 pandemic", Journal of International Consumer Marketing, Vol.33, No.1:58-67.

https://www.who.int/health-topics/coronavirus\#tab=tab_1 (e.t. 01.07.2020)

https://www.worldometers.info/coronavirus/ (e.t: 01.07.2020)

https://covid19.saglik.gov.tr/ (e.t:01.07.2020) 